\title{
ARTICLE
}

\section{Nutritional condition and gonad development of juvenile and subadult California spiny lobster Panulirus interruptus in two habitats}

\author{
Condición nutricional y desarrollo gonádico de juveniles y subadultos de \\ langosta roja, Panulirus interruptus, en dos hábitats

\section{Oswaldo U. Rodríguez-García ${ }^{1}$, Verónica Castañeda-Fernández de Lara ${ }^{2}$, Carmen Rodríguez-Jaramillo ${ }^{1}$ and Elisa Serviere-Zaragoza ${ }^{1}$}

\begin{abstract}
${ }^{1}$ Centro de Investigaciones Biológicas del Noroeste (CIBNOR), Calle IPN 195, La Paz, B.C.S. 23096, México. serviere04@ cibnor.mx

${ }^{2}$ Centro Regional de Investigación Pesquera (CRIP), La Paz-INAPESCA, Carretera a Pichilingue Km 1, La Paz, B.C.S 23020, México

Resumen.- Se analizó la condición nutricional y el desarrollo gonádico de juveniles y sub-adultos de langosta roja (Panulirus interruptus) en 2 sitios de la Península de Baja California cercanos geográficamente, pero con condiciones ambientales contrastantes, el más norteño con condiciones subtropicales y el sureño con condiciones semitempladas. Se estimaron el índice hepatosomático y el índice refractivo de la sangre, y se cuantificaron las proteínas, lípidos y carbohidratos del hepatopáncreas en 62 langostas. Adicionalmente, se comparó el desarrollo gonádico de los organismos en ambos sitios. El índice hepatosomático y la cuantificación de lípidos mostraron que la condición nutricional de los organismos fue diferente en cada sitio. Se observó que los índices de condición nutricional son afectados por el desarrollo gonádico debido al uso de reservas para la maduración de las gónadas. La condición nutricional y el desarrollo gonádico están fuertemente relacionados con las condiciones ambientales donde se encuentran las langostas, lo cual es información útil para el manejo de la pesquería de P. interruptus.
\end{abstract}

Palabras clave: Langosta, Panulirus interruptus, reproducción, condición nutricional, Península de Baja California

\begin{abstract}
The nutritional condition of juveniles and subadults of the California spiny lobster (Panulirus interruptus) from 2 sites along the west coast of the Baja California Peninsula, near each other but with contrasting environmental conditions were compared. The northern site presents subtropical environmental conditions and the southern has semi-temperate. The hepatosomatic and blood refractive indices and proteins, lipids, and carbohydrates from the hepatopancreas in 62 lobsters were assayed. Gonad development of the lobsters between the 2 sites was compared. The hepatosomatic index and lipids of the lobsters at each site were different. The nutritional condition indices are affected by gonad development tied to the reserves needed for maturation of the gonads. Nutritional condition and gonad development are strongly related to environmental conditions. This is key to efforts in spiny lobster fishery management.
\end{abstract}

Key words: Lobster, Panulirus interruptus, reproduction, nutritional condition, Baja California Peninsula

\section{INTRODUCTION}

The California spiny lobster Panulirus interruptus (J.W. Randall, 1840) is the most important commercially fished lobster off the western coast of the Baja California Peninsula, representing 94\% of the lobster fishery in the region (Vega-Velázquez 2006). This species is distributed along the Pacific coast from the border with the United States to Isla Santa Margarita $\left(24.5^{\circ} \mathrm{N}, 111.8^{\circ} \mathrm{W}\right)$. In the region, temperatures vary from subtropical to temperate, mostly tied to the flow of the California Current (VegaVelázquez et al. 1996). Some small lobster populations are found to the tip of the peninsula and inside of the Gulf of California (Ayala-Martínez et al. 1988, Fischer et al. 1995).
This species inhabits the intertidal zone to a depth of 150 m (Ayala-Martínez et al. 1988, Vega-Velázquez et al. 1996) in rocky crevice or rocky-sandy areas, sometimes at the holdfast of the brown algae Macrocystis spp. (Phillips et al. 1980, Fischer et al. 1995). It is omnivorous and opportunistic (Díaz-Arredondo \& Guzmán-del-Proó 1995, Vega-Velázquez et al. 2000, Castañeda-Fernández de Lara 2005). Its diet consists mainly of shellfish and different seasonally abundant trophic groups (Díaz-Arredondo \& Guzmán-del-Proó 1995, Castañeda-Fernández de Lara 2005a). 
In several lobster species, nutritional condition is an indicator of the quantity and quality of food they consume and a survival tactic for increasing reserves for physiological functioning and growth (Dall 1975, Robertson et al. 2000, Oliver \& MacDiarmid 2001). Quick measurements of nutritional condition in marine animals are a useful tool for ecologists because they provide estimates of individuals inhabiting different environments, as well as environmental changes (Robertson et al. 2000). One commonly used quick method is the blood refractive index (BRI). This index is directly proportional to the amount of serum proteins in the blood. It is used as a reliable estimator of nutritional condition, as long as the lobster molt stage is taken into account (Oliver \& MacDiarmid 2001, Ozbay \& Riley 2002).

For lobsters along the Baja California Peninsula, there are few studies of nutritional condition. Díaz-Arredondo \& Guzmán-del-Proó (1995) found lower levels of nutritional condition during spring and autumn, in the spawning period. They also found that the reserve index (RI) was higher in autumn because the lobsters were preparing for reproductive activity. Based on the hepatosomatic index (HI), Castañeda-Fernández de Lara et al. (2005a) found differences in the nutritional condition of juveniles related to site and season, based on the differences in the food quality at each site.

In this study, we compared the nutritional condition of the California spiny lobster by estimating the HI and BRI at 2 sites that are geographically close, but have contrasting environmental conditions. The indices were compared with the assays of lipid, protein, and carbohydrate content in the hepatopancreas. To determine if the nutritional indices were related to reproduction, gonad development was also studied.

\section{Materials AND METHODS}

\section{STUdY AREA}

Juvenile and subadult California spiny lobster (smaller than $60 \mathrm{~mm}$ cephalothorax length) were caught at 2 sites on the west coast of the Baja California Peninsula (Fig. 1). Although the sites are close, they have very different environmental conditions related to coastal current dynamics. The cove where the fishing camp Arvin


Bahía Tortugas. The California Current directly impacts this site. This cove is largely composed of sea grass Phyllospadix scouleri (W.J. Hooker, 1838) and eelgrass
Zostera marina (Linnaeus, 1753) and brown seaweed of temperate affinity [Macrocystis pyrifera (Linneaus) C. Agardh, 1820, Sargassum muticum (Yendo) Fensholt, 1955, and Cystoseira osmundacea (Turner) Agardh, 1820], which were previously studied (Castañeda-Fernández de Lara et al. 2005b, 2010). The cove of the fishing camp

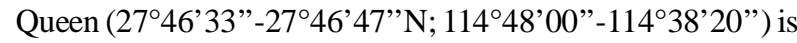
located in Bahía Sebastian Vizcaino. An anticyclonic eddy circulation produces a warm water mass inside Bahía Sebastian Vizcaino (Amador-Buenrostro et al. 1995). The dominant flora is seagrass Phyllospadix torreyi (S. Watson, 1879) and some tropical brown algae Padina spp. and Sargassum agardhianum (Farlow) Agardh, 1889 (Dawson 1952, Castañeda-Fernández de Lara et al. 2005b, 2010).
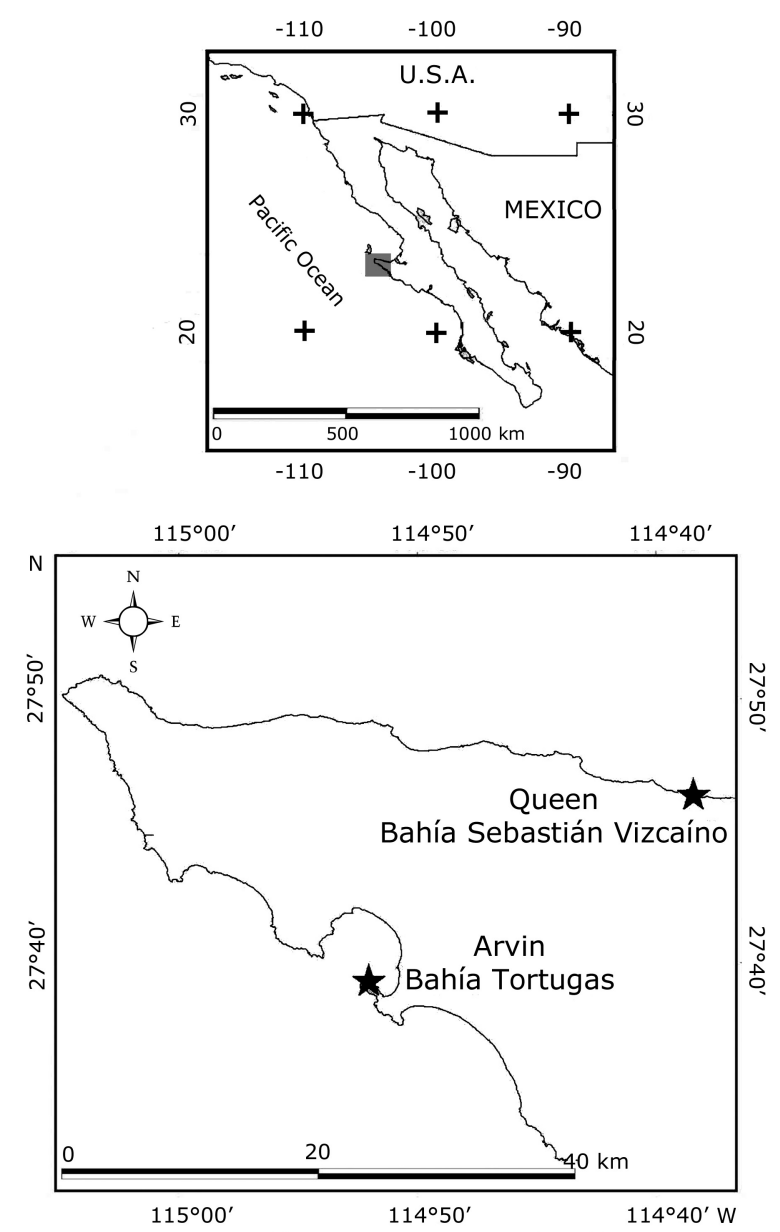

Figure 1. Study sites along the Pacific coast of the Baja California Peninsula / Sitios de estudio en la costa occidental de la península de Baja California 
In May 2004, lobsters were caught in octopus traps modified with larger entrances. The traps were set in the afternoon, baited with fish, and collected the following morning. Three variables were recorded: carapace length $(\mathrm{CL} \pm 0.1 \mathrm{~mm})$ using a vernier caliper, total weight $(\mathrm{TW} \pm$ $0.01 \mathrm{~g}$ ) with a digital scale, and the sex of each lobster.

\section{DisSECTION OF THE HEPATOPANCREAS AND GONAD}

From each lobster, the hepatopancreas was removed and weighed $( \pm 0.1 \mathrm{~g} \mathrm{HW})$. The tissues were placed in Eppendorf tubes inside a vessel of liquid nitrogen for transport to the laboratory and subsequent biochemical analysis. Gonads were removed and fixed for $48 \mathrm{~h}$ in modified Davidson's solution (22\% formaldehyde, $33 \%$ ethanol, $11.5 \%$ glacial acetic acid, and $33.5 \%$ filtered marine water) (Shaw \& Battle 1957) and then placed in $70 \%$ alcohol for transport and subsequent histological analysis.

\section{Determination OF MOLT STAGE}

Two to 3 pleopods from each lobster were removed and placed in bottles of $10 \%$ formaldehyde for further review in the laboratory. Each specimen was classified as either premolt, intermolt, and postmolt (Lyle \& MacDonald 1983).

\section{NUTRITIONAL CONDITION INDICES}

The TW/CL ratio and the hepatosomatic index (HI= (TW ( DGW) $\times 100$ ) were used as nutritional condition indices (Briones-Fourzán et al. 2003, Castañeda-Fernández de Lara et al. 2005a).

Blood Refractive Index (BRI). Prior to dissection, $1 \mathrm{~mL}$ of blood was withdrawn from the pericardial sinus with a small syringe. The BRI was read directly from a portable refractometer (Leica IFT40). The value of the BRI was compared with a normal curve established with different concentrations of bovine serum albumin to determine the level of serum protein (Oliver \& MacDiarmid 2001). Estimates of protein concentration in the blood of the specimens were calculated from the regression equation of the standard curve $\mathrm{y}=0.0982 \mathrm{x}, \mathrm{R}^{2}=0.9847$, where $\mathrm{y}=$ refractometer, $\mathrm{x}=$ amount of protein (Castañeda-Fernández de Lara et al. 2005a).

\section{BIOCHEMICAL COMPOSITION}

The hepatopancreas samples preserved in liquid nitrogen were lyophilized to standardize the amount of water, then placed in Eppendorf tubes. We added $0.050 \mathrm{~g}( \pm 0.009 \mathrm{~g})$ to $0.5 \mathrm{~mL}$ aliquots of isotonic crustacean solution (450 $\mathrm{mM} \mathrm{NaCl}, 10 \mathrm{mM} \mathrm{KCl}, 1 \mathrm{mM}$ PMSF) and homogenized the mixture, followed by adding $1 \mathrm{~mL}$ ICS and stirred in a vortex.

As assay of soluble proteins the modified Bradford method was utilized (Bradford 1976) and read with a spectrophotometer at $595 \mathrm{~nm}$. Assay of the carbohydrates used the modified anthrone method (Roe et al. 1961) and read at $540 \mathrm{~nm}$ in colorimeter plates. Assay of lipids used the modified vanillin method (Barnes \& Blackstock 1973) and read with a spectrophotometer at $540 \mathrm{~nm}$.

\section{GONAD DEVELOPMENT}

The gonads of subadults were sectioned ( $4 \mu \mathrm{m}$ thick). Conventional staining with hematoxylin-eosin was applied to determine the stage of gonad development in males and females (Sheehan \& Hrapchak 1973). Five digital photographs were taken of each cut and analyzed with an image analysis system (Image Pro Plus 4.5.19) attached to an Olympus BX41 compound microscope and digital camera (Pro CoolSnap) connected to a computer.

The testis and vas deferens of the males were studied, and the sperm cells were classified according to the stage of spermatogenesis (spermatogonia, spermatocytes, spermatids, and spermatozoa) (Shigekawa \& Clark 1986). Males who had spermatids and spermatozoa gonads were classified as mature (Harley 1984).

In females, substages and stages of oogenesis were classified by the modified morphological description of Minagawa \& Sano (1997) for Panulirus japonicus (Von Siebold, 1824), where the oocytes are observed in an approximately equatorial planar cut of the nucleoplasm. Five categories of oogenesis and their respective substages and a stage of oocyte resorption were used: (1) Multiplication (oogonia), (2) previtellogenesis (oocytes with early chromatin nucleolus), (3) late primary vitellogenesis (oocytes with lipid inclusions), (4) secondary vitellogenesis (oocytes with yolk granules), (5) maturity (mature oocytes), (6) resorption (atretic oocytes). The area of oocytes was used to calculate the theoretical diameter (TD), as described by Saout et al. (1999), using a standardized measurement based on the equation for the circumference, as follows:

$$
T D=\sqrt{\frac{4 A}{\pi}},
$$

where, TD is the theoretical diameter and A is the area 


\section{Data ANALysis}

Normality of the biological data was tested by the Kolmogorov-Smirnov test $(\alpha=0.20)$, and the Bartlett for homogeneity of variances $(\alpha=0.05)$ (Sokal \& Rohlf 1998). Significant differences were estimated with two-way ANOVA, using independent variables (site and sex) and dependent variables (TL, CL, TW, HI, BRI, and protein, carbohydrates and lipids concentrations) $(\alpha=0.05)$. To find means that were significantly different, we used the Tukey range test $(\alpha=0.05)$ (Sokal \& Rohlf 1998). Differences in oocyte categories were determined by the Kruskal-Wallis nonparametric ANOVA $(\alpha=0.05)$, since the data failed to reach the assumptions of normality and homogeneity of variances (Sokal \& Rohlf 1998). All analyzes were performed with the program Statistica 6.0 (StatSoft, Tulsa, OK).

\section{Results}

Of 62 lobsters, 30 were collected from Queen and 32 from Arvin; there were 26 females and 36 males. From Queen, 13 were females ( 11 intermolt, 2 premolt) and 17 were males (13 intermolt, 4 premolt). From Arvin, 13 were females (10 intermolt, 3 premolt) and 19 were males (15 intermolt, 4 premolt). At Queen, the lobsters were larger $\left(\mathrm{F}_{(1,54)}=4.36\right.$, $P<0.05)$ and weighed more $\left(\mathrm{F}_{(1,54)}=8.35, P<0.05\right)$; there were no significant differences between sexes, or interactions between factors (Table 1). The same results occur with the molt stage.
Table 1. Biometrics and sex of juvenile and subadult California spiny lobster Panulirus interruptus from 2 sites, including mean, standard error ( \pm ), total length (TL), carapace length (CL), total weight (TW), and hepatopancreas weight (HW) / Morfometrías y sexo de juveniles y subadultos de langosta roja Panulirus interruptus de 2 sitios con media, error estándar $( \pm)$, longitud total (TL), longitud del cefalotórax (CL), peso total (TW) y peso del hepatopáncreas (HW)

\begin{tabular}{cccccc}
\hline $\begin{array}{c}\text { Level of } \\
\text { Factor }\end{array}$ & $\mathrm{N}$ & $\begin{array}{c}\mathrm{TL} \\
(\mathrm{mm})\end{array}$ & $\begin{array}{c}\mathrm{CL} \\
(\mathrm{mm})\end{array}$ & $\begin{array}{c}\text { TW } \\
(\mathrm{g})\end{array}$ & $\begin{array}{c}\text { HW } \\
(\mathrm{g})\end{array}$ \\
\hline $\begin{array}{c}\text { Total } \\
\text { Queen }\end{array}$ & 62 & $164.79 \pm 3.11$ & $50.40 \pm 1.00$ & $119.24 \pm 5.57$ & $3.71 \pm 0.19$ \\
$\quad$ Arvin & 32 & $160.22 \pm 4.07$ & $49.02 \pm 1.48^{\mathrm{b}}$ & $106.20 \pm 6.85^{\mathrm{b}}$ & $3.52 \pm 0.21$ \\
Sex & & & & & \\
$\quad$ Female & 26 & $162.54 \pm 5.78$ & $48.32 \pm 1.46$ & $117.01 \pm 9.15$ & $3.98 \pm 0.31$ \\
$\quad$ Male & 36 & $166.42 \pm 3.41$ & $51.91 \pm 1.31$ & $120.85 \pm 7.05$ & $3.52 \pm 0.22$ \\
\hline $\begin{array}{l}\text { Queen } \\
\text { Female }\end{array}$ & 13 & $168.23 \pm 8.78$ & $50.21 \pm 1.96^{\mathrm{b}}$ & $133.42 \pm 13.75$ & $4.12 \pm 0.46$ \\
$\quad \begin{array}{l}\text { Male } \\
\text { Arvin }\end{array}$ & 17 & $170.76 \pm 4.94$ & $53.15 \pm 1.70^{\mathrm{ab}}$ & $132.94 \pm 10.52$ & $3.78 \pm 0.42$ \\
$\quad$ Female & 13 & $156.85 \pm 7.52$ & $46.42 \pm 2.12^{\mathrm{ab}}$ & $100.60 \pm 10.72$ & $3.85 \pm 0.44$ \\
Male & 19 & $162.53 \pm 4.64$ & $50.79 \pm 1.96^{\mathrm{a}}$ & $110.03 \pm 9.03$ & $3.28 \pm 0.19$ \\
\hline
\end{tabular}

*letters in the same column indicate mean significant differences
Table 2. Nutritional condition indices of juvenile and subadult California spiny lobster Panulirus interruptus, including mean and standard error $( \pm)$, ratio of weight to cephalothorax length (TW/CL), hepatosomatic index (HI), blood refractive index (BRI), and hepatopancreas content of proteins, carbohydrates, and lipids / Índices de condición nutricional de juveniles y adultos de langosta roja Panulinus interruptus incluyendo medias y error estándar $( \pm)$ relación peso total-longitud del cefalotórax (TW/CL), índice hepatosomático (HI), índice refractivo de la sangre (BRI) y cuantificación de proteínas, carbohidratos y lípidos en el hepatopáncreas

\begin{tabular}{|c|c|c|c|c|c|c|c|}
\hline $\begin{array}{l}\text { Level of } \\
\text { Factor }\end{array}$ & $\mathrm{N}$ & $\begin{array}{l}\mathrm{TW} / \mathrm{CL} \\
\left(\mathrm{g} \cdot \mathrm{mm}^{-1}\right)\end{array}$ & $\mathrm{HI}$ & $\begin{array}{c}\mathrm{BRI} \\
\left(\mathrm{mg} \cdot \mathrm{L}^{-1}\right)\end{array}$ & $\begin{array}{l}\text { Protein } \\
\left(\mathrm{mg} \cdot \mathrm{g}^{-1}\right)\end{array}$ & $\begin{array}{l}\text { Carbohydrates } \\
\left(\mathrm{mg} \cdot \mathrm{g}^{-1}\right)\end{array}$ & $\begin{array}{l}\text { Lipids } \\
\left(\mathrm{mg} \cdot \mathrm{g}^{-1}\right)\end{array}$ \\
\hline Total & 62 & $2.30 \pm 0.08$ & $3.21 \pm 0.11$ & $131.32 \pm 3.47$ & $75.18 \pm 2.37$ & $66.32 \pm 2.81$ & $195.33 \pm 9.54$ \\
\hline Queen & 30 & $2.49 \pm 0.11^{\mathrm{a}}$ & $2.93 \pm 0.14^{\mathrm{a}}$ & $123.39 \pm 5.38$ & $74.45 \pm 4.13$ & $70.93 \pm 3.57$ & $175.82 \pm 12.30$ \\
\hline Arvin & 32 & $2.12 \pm 0.10^{\mathrm{b}}$ & $3.47 \pm 0.14^{\mathrm{b}}$ & $138.75 \pm 4.12$ & $75.87 \pm 2.53$ & $62.01 \pm 4.07$ & $213.62 \pm 13.86$ \\
\hline \multicolumn{8}{|l|}{ Sex } \\
\hline Female & 26 & $2.33 \pm 0.13$ & $3.50 \pm 0.16^{\mathrm{a}}$ & $135.71 \pm 5.71$ & $69.78 \pm 3.43$ & $60.39 \pm 3.51$ & $227.36 \pm 17.41^{\mathrm{a}}$ \\
\hline Male & 36 & $2.28 \pm 0.09$ & $2.99 \pm 0.14^{\mathrm{b}}$ & $128.14 \pm 4.32$ & $79.08 \pm 3.13$ & $70.61 \pm 4.01$ & $172.20 \pm 08.98^{\mathrm{b}}$ \\
\hline \multicolumn{8}{|l|}{ Queen } \\
\hline Female & 13 & $2.57 \pm 0.21$ & $3.14 \pm 0.21$ & $130.42 \pm 9.47$ & $73.44 \pm 5.99$ & $65.17 \pm 4.79$ & $188.38 \pm 24.65$ \\
\hline Male & 17 & $2.44 \pm 0.13$ & $2.77 \pm 0.19$ & $118.01 \pm 6.08$ & $75.22 \pm 5.83$ & $75.33 \pm 5.39$ & $166.22 \pm 11.05$ \\
\hline \multicolumn{8}{|l|}{ Arvin } \\
\hline Female & 13 & $2.10 \pm 0.50$ & $3.87 \pm 0.18$ & 141.00 & 66.13 & 55.6 & $266.33 \pm 20.03$ \\
\hline Male & 19 & $2.14 \pm 0.13$ & $3.19 \pm 0.18$ & $137.21 \pm 5.46$ & $82.53 \pm 2.76$ & $66.38 \pm 5.85$ & $177.55 \pm 14.02$ \\
\hline
\end{tabular}

*letters in the same column indicate mean significant differences 


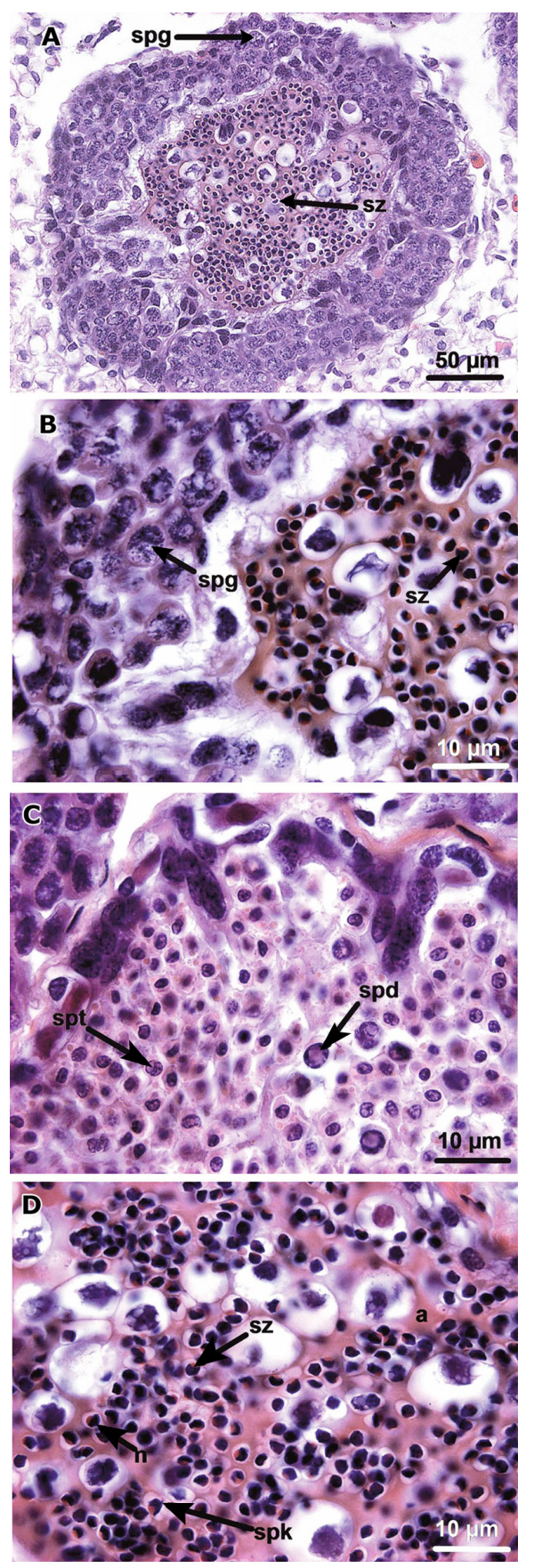

Figure 2. Hematoxylin-eosin stained section of testes of young male California spiny lobster Panulirus interruptus: (A) and (B) spermatogonia (spg). (C) primary and secondary spermatocytes (spt); spermatids (spd). (D) spermatozoa (sz) with marginal nucleus ( $n$ ) and spike (spk) surrounded by acellular spermatophore (a) / Sección de testicular de machos jóvenes de langosta roja Panulirus interruptus teñida con hematoxilina-eosina: (A) y (B) espermatogonias (spg). (C) espermatocitos primarios y secundarios (spt); espermátidas (spd). (D) espermatozoos (sz) con núcleo marginal (n) y spike (spk) rodeado por un espermatóforo acelular (a)
Analysis of the nutritional indices indicated significant differences between sites, including TW/CL ratio $\left(\mathrm{F}_{(1,54)}=\right.$ 7.92, $P<0.05)$ (higher at Queen) and the $\mathrm{HI}\left(\mathrm{F}_{(1,54)}=6.46\right.$, $P<0.05$ ) (higher at Arvin). Also, the HI was significantly different between sexes $\left(\mathrm{F}_{(1,54)}=14.73, P<0.05\right)$. The hepatopancreas biochemical composition did not have significant differences between sites. Lipids were significantly higher in females $\left(227.36 \mathrm{mg} \mathrm{g}^{-1}\right)$ than males $\left(172.20 \mathrm{mg} \mathrm{g}^{-1}\right)\left(\mathrm{F}_{(1,54)}=15.61, P<0.05\right)$ (Table 2).

Gonad histological examination was performed on 44 lobsters. The developmental stage of male gonads was based on the presence of spermatids and spermatozoa (Fig. 2). Of 13 males from Arvin, 6 were immature and 7 were mature. Of 12 males from Queen, one immature and 11 were matures (Fig. 3).

We defined 8 oocytes types and 5 developmental stages of oogenesis. There were 2 phases of the vitellogenesis stage, based on oocyte morphology and diameter (Table 3, Fig. 4). At Arvin, more ovaries contained oocytes at vitellogenesis I and, to a lesser extent, at previtellogenic, vitellogenic II, and oogonia. There were no fully mature oocytes. At Queen, all 5 oocytes types were identified, with similar amounts of previtellogenic, vitellogenic and mature oocytes and, to a lesser extent, vitellogenic II and oogonia (Fig. 5). At Queen, females had significantly larger eggs $(121.06 \pm 23.56)$ than females at Arvin $(63.60 \pm 9.99)\left(\mathrm{F}_{(1,472)}=11.21, P<0.01\right)$. The theoretical diameter increased as oocytes matured from oogonia stage $(13.45 \mu \mathrm{m} \pm 5.45)$ to mature oocytes (393.15 $\mu \mathrm{m} \pm 2.97$ ) (Fig. 6).

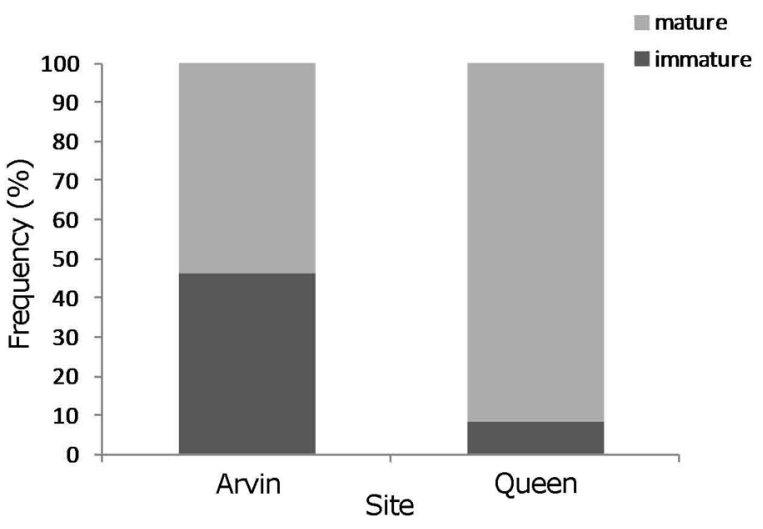

Figure 3. Frequency of mature and immature males of California spiny lobster Panulirus interruptus sampled at Arvin and Queen on the Pacific coast of the Baja California Peninsula / Frecuencia de machos maduros en inmaduros de langosta roja $P$. interruptus muestreados en Arvin y Queen en la costa Pacífico de la península de Baja California 



Figure 4. Hematoxylin-eosin stained sections showing stages of oogenesis and oocyte substages in female California spiny lobster Panulirus interruptus. (A) M ultiplication stage, oogonial nest (og), and previtellogenesis stage and early chromatin nucleolus substage (ec). (B) Previtellogenesis stage and late chromatin nucleolus substage (IC). (C) Vitellogenesis I, (endogenous vitellogenesis) oil globule substage (ogl). (D) Vitellogenesis II (exogenous vitellogenesis), yolk platelet substage (yp). (E) Maturation stage, mature oocyte (mo). (F) Atresia of yolked oocyte; nucleus (n), nucleolus (nc), follicle cell (fc), atretic oocyte (ao) / Estadios de la ovogénesis y subestadios de los ovocitos en hembras de P. interruptus. Sección teñida con hematoxilinaeosina. (A) Estadio de multiplicación, ovogonia (og) y previtelogénesis, nucléolo cromatina temprana (ec). (B) Previtelogénesis, nucléolo cromatina tardía (Ic). (C) Vitelogénesis I (vitelogénesis endógena) gotas lipídicas (ogI). (D) Vitelogénesis II (vitelogénesis exógena), gránulo de vitelo (yp). (E) Maduración, ovocito maduro (mo). (F) Atresia en ovocito con vitelo; núcleo (n), nucléolo (nc), células foliculares (fc), ovocito atrésico (ao)

Table 3. Developmental stages of oogenesis in female California spiny lobster Panulirus interruptus including mean and standard error ( \pm ) theorical diameter of oocytes types. / Estadios del desarrollo ovogénico en hembras de langosta roja Panulirus interruptus incluyendo medias y error estándar $( \pm)$ del diámetro teórico de los diferentes tipos de ovocitos

\begin{tabular}{lcc}
\hline Stage of oogenesis & $\begin{array}{c}\text { Substages (types of } \\
\text { oocytes) }\end{array}$ & $\begin{array}{c}\text { Panulirus interruptus } \\
\text { diameter }(\mu \mathrm{m})\end{array}$ \\
\hline Multiplication & Oogonia & $13.45 \pm 5.45$ \\
Previtelogenesis & $\begin{array}{c}\text { Early chromatin nucleolus } \\
\text { Late chromatin nucleolus }\end{array}$ & $30.46 \pm 2.41$ \\
Vitelogenic I & Lipid inclusions & $73.93 \pm 2.15$ \\
Vitelogenic II & Yolk platelet substage & $181.46 \pm 3.98$ \\
Maturity $\quad$ Mature & $393.15 \pm 2.97$ \\
Resorption & Atretic oocytes & \\
\hline
\end{tabular}

${ }^{1}$ Minagawa \& Sano (1997)

\section{Discussion}

On the west coast of the Baja California Peninsula, juvenile and subadult California spiny lobsters Panulirus interruptus collected at 2 fishing camps differed in nutritional condition and gonad development. The average cephalothorax length and total weight of lobsters from Arvin was lower than lobsters from Queen. This is consistent with advanced gonad development and higher total weight of lobsters from Queen.

Differences in nutritional condition and gonad development of lobsters from the 2 sites are related to water temperature. On average, Queen $\left(19.9^{\circ} \mathrm{C}\right)$ is warmer than Arvin $\left(17.3^{\circ} \mathrm{C}\right)$ (Castañeda-Fernandez de Lara et al. 


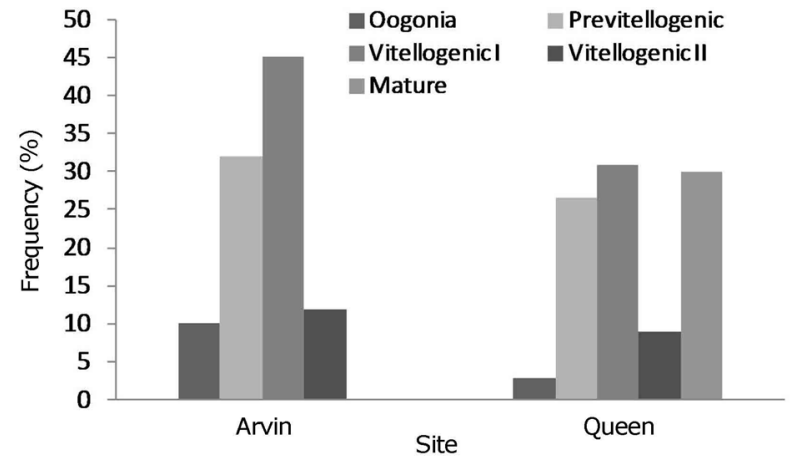

Figure 5. Frequency of oogenesis stages in female California spiny lobster Panulirus interruptus sampled at Arvin and Queen / Frecuencia de los estadios ovogénicos en hembras de Panulirus interruptus muestreados en Arvin y Queen

2005b). Faster gonad development has been found in Panulirus ornatus (Fabricius, 1798) under laboratory conditions (Sachlikidis et al. 2005). The higher water temperature at Queen $\left(2.6^{\circ} \mathrm{C}\right)$ leads to larger lobsters because the duration of the intermolt is shorter (Thomas et al. 2000, Hazell et al. 2001). Additional variables may include favorable environment conditions, such as more dense and more nutritional food (Leocádio \& Cruz 2008).

Even though proteins, carbohydrates, and lipids did not have significant differences between sites, the HI indicates that lobsters at Arvin had a better nutritional condition. Carbohydrate content has no important effect on nutritional condition (Simon \& Jeffs 2011). With rapid growth of juveniles, changes in proteins are better reflected, in integument tissue than in the hepatopancreas because it forms a principal component of the exoskeleton (Travis 1955). Like weight, nutritional condition may be related to gonad development. In female lobsters, lipids are transported from the hepatopancreas to the ovaries during vitellogenesis (Sánchez-Paz et al. 2006), which explains why the hepatopancreas from lobsters from Arvin had higher HI.

Castañeda-Fernández de Lara et al. (2005a) found that juveniles from Arvin have higher nutritional condition than lobsters from Queen in autumn 2001 and winter 2002, and nutritional condition of lobsters from Arvin was lowest during spring and summer 2002. In our study, lobsters from Arvin had higher nutritional condition in spring 2004. This is related to differences in gonad development between the 2 sites, as mentioned above. Briones-Fourzán et al. (2003) reported that the nutritional

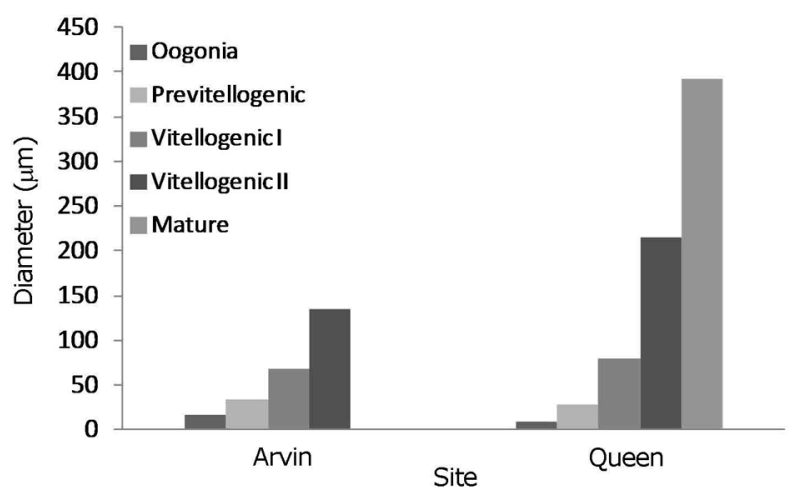

Figure 6. Oocytes diameter at different stages of oogenesis in female California spiny lobster Panulirus interruptus sampled at Arvin and Queen / Frecuencia del diámetro de los ovocitos en diferentes estadios ovogénicos en hembras de Panulirus interruptus capturados en Arvin y Queen

condition in subadults is less than in juveniles. This is caused by the energy requirements at the beginning of the reproductive cycle, when sugars, lipids and lipoproteins are transported from the hepatopancreas to the ovary. This has been documented for crabs, shrimp, freshwater crayfish, and lobsters (Aiken \& Waddy 1980, Sánchez-Paz et al. 2006, Ferré et al. 2012).

Mature lobsters were smaller at maturity $(72.6 \mathrm{~mm} \mathrm{CL})$ than lobsters in the study of Vega-Velázquez (2003) at the same area. At Punta Malarrimo (near Queen), TapiaVázquez \& Castro-González (2000) reported that lobsters at first spawning were in the range of 57-82 $\mathrm{mm} \mathrm{CL}$. Lobsters from Queen had more advanced stages of gonad development than lobsters from Arvin for the same size (Pineda-Barrera et al. 1981), and fertility along the Pacific coast of the Baja California Peninsula increases from north to south; Punta Malarrimo (near Queen) has the highest fertility throughout the peninsula (Pineda-Barrera $e t$ al. 1981). There are several hypotheses why there are latitudinal differences in the size at maturation of crustaceans, such as density and exploitation (MelvilleSmith \& de-Lestang 2006), but the most widely accepted hypothesis is that warmer waters favor faster maturity in smaller crustaceans (Aiken \& Waddy 1980, Phillips et al. 1980).

The difference in gonad maturation in lobsters of the same size is influenced by temperature (Hunt \& Lyons 1986, Thomas et al. 2000, Hazell et al. 2001). Hence, the $2.6^{\circ} \mathrm{C}$ higher temperature at Queen may cause faster development of gonads. The ecological model that exemplifies these differences can be observed in 
ectothermic species (Van der Have 2008). Also, differences in the gonad development may reflect the preference of juveniles at Arvin for sea grass and eelgrass (CastañedaFernández de Lara 2005b). There may also be found differences at genetic level caused by isolation of the sites, related to the anticyclone gyre at Bahía Sebatían Vizcaíno, as was shown in the European spiny lobster Palinurus elephas (Fabricius, 1787) (Palero et al. 2011). These potential causes will require more studies. Finally, with increasing climate change, environmental conditions should be considered in management programs to avoid capture of lobsters at first maturity or in less than optimal nutritional condition to maintain stocks at optimal sustainability.

\section{ACKNOWLEDGMENTS}

We thank the staff of the Langosta Project at Centro Regional de Investigación Pesquera (CRIP-La Paz) for their support. We thank the people from CIBNOR Juan José Ramírez for field support, Eulalia Meza for help in preparing histological material and Ira Fogel for important editorial services provided. Project funding was received from the Consejo Nacional de Ciencia y Tecnología of Mexico (CONACYT 35151-B) and the U.S. National Science Foundation (NSF 995-00410439/CIBNOR) led by Salvador Lluch Cota.

\section{LITERATURE CITED}

Aiken DE \& SL Waddy. 1980. Reproductive biology. In: Cobb JS \& BF Phillips (eds). The biology and management of lobsters, Vol 1, Physiology and behavior: 215-276. Academic Press, New York.

Amador-Buenrostro A, ML Argote-Espinoza, M MancillaPeraza \& M Figueroa-Rodríguez. 1995. Variaciones de periodo corto de la circulación anticiclónica en Bahía Sebastián Viszcaíno, BC. Ciencias Marinas 21(2): 201-223.

Ayala-Martínez Y, J González-Ávila \& JG EspinozaCastro. 1988. Biología y pesca de la langosta del Pacífico mexicano En: Los recursos pesqueros masivos del país. XXV Aniversario del Instituto Nacional de Pesca, pp. 267286. Secretaría de Pesca, SEPESCA / Instituto Nacional de Pesca, México.

Barnes H \& J Blackstock. 1973. Estimation of lipids in marine animals and tissues: detailed investigation of the sulphophosphovanillin method for 'total' lipids. Journal of Experimental Marine Biology and Ecology 12: 103-118.

Bradford MM. 1976. A rapid and sensitive method for the quantitation of microgram quantities of protein utilizing the principle of protein-Dye binding. Analytical Biochemistry 72: 248-254.
Briones-Fourzán P, V Castañeda-Fernández de Lara, E Lozano-Álvarez \& J Estrada-Olivo. 2003. Feeding ecology of the three juvenile phases of the spiny lobster Panulirus argus in a tropical reef lagoon. Marine Biology 142: 855-865.

Castañeda-Fernández de Lara V. 2005. Caracterización del hábitat de juveniles de la langosta roja Panulirus interruptus (Randall, 1839) en dos sitios ubicados en su zona de mayor abundancia en Baja California Sur, México. Tesis de Doctorado, Centro de Investigaciones Biológicas del Noroeste, La Paz, 131 pp.

Castañeda-Fernández de Lara V, E Seviere-Zaragoza, S Hernández-Vázquez \& MJ Butler IV. 2005a. Feeding ecology of juvenile spiny lobster Panulirus interruptus at the north Pacific coast of Baja California Sur, Mexico. New Zealand Journal of Freshwater Research 39: 425-435.

Castañeda-Fernández de Lara V, MJ IV Butler, S Hernández-Vázquez, S Guzmán del Próo, \& E Serviere-Zaragoza. 2005b. Determination of preferred habitats of early benthic juvenile California spiny lobster, Panulirus interruptus, on the Pacific coast of Baja California, Mexico. Marine and Freshwater Research 56: 1037-1045.

Castañeda-Fernández de Lara V, H Reyes-Bonilla, E Serviere-Zaragoza. 2010. A tropical assemblage of benthic macroalgae on rocky reefs in a temperate zone on the western Baja California peninsula, Mexico. Botanica Marina 53: 195-203.

Dall W. 1975. Indices of nutritional state in the Western Rock Lobster Panulirus longipes (Milne Edwards). II. Gastric fluid constituent. Journal of Experimental Marine Biology and Ecology 18: 1-18.

Dawson EY. 1952 .Circulation within Bahía Vizcaino, Baja California, and its effects on marine vegetation. American Journal of Botany 39: 425-432.

Díaz-Arredondo MA \& SA Guzmán-del-Próo. 1995. Hábitos alimentarios de la langosta roja (Panulirus interruptus Randall, 1840) en Bahía Tortugas, Baja California Sur. Ciencias Marinas 21: 439-462.

Ferré L, DA Medesani, CF García, M Grodzielski \& EM Rodríguez. 2012. Vitellogenin levels in hemolymph, ovary and hepatopancreas of the freshwater crayfish Cherax quadricarinatus (Decapoda: Parastacidae) during the reproductive cycle. Revista de Biología Tropical 60(1): 253261.

Fischer W, F Krupp, W Schneider, C Sommer, KE Carpenter \& VH Niem. 1995. Volumen I. Plantas e invertebrados. Guía FAO para la identificación de especies para los fines de pesca Pacífico centro-oriental, 646 pp. FAO, Rome.

Follesa MC, D Cuccu, R Cannas, S Cabiddu, M Murenu, A Sabatini \& A Cau. 2008. Effects of marine reserve protection on spiny lobster (Palinurus elephas Fab., 1787) in a central western Mediterranean area. Hydrobiologia 606: 63-68. 
Harley S. 1984. Spermatogenesis and spermatophore production in the Hawaiian red Lobster Enoplometopus occidentalis (Randall) (Crustacea, Nephropidae). Journal of Morphology 180: 181-193.

Hazell RWA, AC Cockcroft, S Mayfield \& M Noffke. 2001. Factors influencing the growth rate of juvenile rock lobsters, Jasus lalandii. Marine and Freshwater Research 52: 13671373.

Hunt HJ \& WG Lyons. 1986. Factors affecting growth and maturation of spiny lobsters, Panulirus argus, in the Florida keys. Canadian Journal of Fisheries and Aquatic Sciences 43: 2243-2247.

Leocádio AM \& R Cruz. 2008. Growth parameters of the spiny lobster (Panulirus argus) in the great Caribbean: a review. Revista de Investigaciones Marinas 29(3): 239-248.

Lyle WG \& CD MacDonald. 1983. Molt stage determination in the Hawaiian spiny lobster Panulirus marginatus. Journal of Crustacean Biology 3(2): 208-216.

Melville-Smith R \& S de-Lestang. 2006. Spatial and temporal variation in the size at maturity of the western rock lobster Panulirus cygnus. Marine Biology 150: 183195.

Minagawa M \& M Sano. 1997. Oogenesis and ovarian development cycle of the spiny lobster Panulirus japonicus (Decapoda: Palinuridae). Marine and Freshwater Research 48: 875-887.

Oliver MD \& AB MacDiarmid. 2001. Blood refractive index and ratio of weight to carapace length as indices of nutritional condition in juvenile rock lobsters (Jasus edwardsii). Marine and Freshwater Research 52(8): 13951400.

Ozbay G \& JG Riley. 2002. An analysis of refractometry as a method of determining blood total protein concentration in the American lobster Homarus americanus (Milne Edwards). Aquaculture Research 33: 557-562.

Palero F, P Abelló, E MacPherson, M Beaumont \& M Pascual. 2011. Effect of the oceanographic barriers and overfishing on the population genetic structure of the European spiny lobster (Palinurus elephas). Biological Journal of the Linnean Society 104(2): 407-418.

Phillips BF, JS Cobb \& RW George. 1980. General biology. In: Cobb JS \& BF Phillips (eds). The biology and management of lobsters, Vol. 1. Physiology and behavior: 1-82. Academic Press, New York.

Pineda-Barrera J, AJ Díaz de León-C \& F Uribe-Osorio. 1981. Fecundidad de la Langosta roja Panulirus interruptus (Randall, 1842) en Baja California. Ciencia Pesquera 1(1): 99-118.

Ponce-Díaz G, MM Casas-Valdez, M Ramírez-Rodríguez, D Lluch-Belda, JL Castro-Ortiz, G De La Cruz-Agüero, A Martínez-de la Torre, A Vélez-Barajas, F GalvánMagaña, R Félix-Uraga, RE Martinez-Pecero, E BalartPáez, R González-Armas, L Stephanie-Mercier, J
Naranjo-Paramo, SR Maciel-Zapata, $R$ de la RosaPacheco, G Martínez-Flores, S Macías-Mejía, V Morales-Zárate, LV Ramos-López, M CarreraFernández \& O Escobar-Sánchez. 2009. Propuesta de Carta Estatal Pesquera y Acuícola del Estado de Baja California Sur, 283 pp. SAGARPA-CONAPESCA, Gobierno del Estado de Baja California Sur-Secretaria de Pesca, CIBNOR-CONACYT, CICIMAR-IPN, La Paz.

Robertson DN, MJ Butler \& FC Dobbs. 2000. An evaluation of lipid-and morphometric-based indices of nutritional condition for early benthic stage spiny lobsters, Panulirus argus. Marine and Freshwater Behavior and Physiology 33(3): 161-171.

Roe JH, JM Bailey, RR Gray \& JN Robinson. 1961. Complete removal of glycogen from tissues by extraction with cold trichloroacetic acid solution. Journal of Biological Chemistry 236(5): 1244-1246.

Sachlikidis NG, CM Jones \& JE Seymour. 2005. Reproductive cues in Panulirus ornatus. New Zealand Journal of Freshwater Research 39(2): 305-310.

Sánchez-Paz A, F García-Carreño, A Muhlia-Almazán, AB Peregrino-Uriarte, J Hernández-López \& G YepizPlascencia. 2006. Usage of energy reserves in crustaceans during starvation: Status and future directions. Insect Biochemistry and Molecular Biology 36(4): 241-249.

Saout C, C Quéré, A Donval, YM Paulet \& JF Samain. 1999. An experimental study of the combined effects of temperature and photoperiod on reproductive physiology of Pecten maximus from the Bay of Brest (France). Aquaculture 172: 301-314.

Shaw GL \& HI Battle. 1957. The gross and microscopic anatomy of the digestive tract of the oyster Crassotreas virginica (Gmelin). Canadian Journal of Zoology 35: 325-346.

Sheehan D \& BB Hrapchak. 1973. Theory and practice of histotechnology, 481 pp. Mosby Company, London.

Shigekawa K \& WH Clark. 1986. Spermiogenesis in the marine shrimp, Sicyonia ingentis. Development, Growth and Differentiation 28(2): 95-112.

Simon CJ \& A Jeffs. 2011. The effect of dietary carbohydrates on the growth response, hepatopancreas glycogen and digestive enzyme activities of early spiny lobster juveniles, Jasus edwarsii. Aquaculture Nutrition 17(6): 613-626.

Sokal RR \& FJ Rohlf. 1998. Biometry: the principles and practice of statistics in biological research, 850 pp. W.H. Freeman \& Company, New York.

Tapia-Vázquez OM \& JJ Castro-González. 2000. Fecundidad y anatomía microscópica del ovario de la langosta roja Panulirus interruptus en Punta Eugenia, Baja California Sur, México. Ciencias Marinas 14: 63-66.

Thomas CW, BJ Crear \& PR Hart. 2000. The effect of temperature on survival, growth, feeding and metabolic activity of the southern rock lobster, Jasus edwardsii. Aquaculture 185(1): 73-84. 
Travis DF. 1955. The molting cycle of the spiny lobster, Panulirus argus Latreille. II. pre-ecdysial histological and histochemical changes in the hepatopancreas and integumental tissues. The Biological Bulletin 108(1): 88112.

Van der Have TM. 2008. Slaves to the Eyring equation? Temperature dependence of life-history characters in developing ectotherms. Ph. D. Thesis, Wageningen University, Wageningen, $167 \mathrm{pp}$.

Vega-Velázquez A. 2003. Reproductive strategies of the spiny lobster Panulirus interruptus related to the marine environmental variability off central Baja California, Mexico: management implications. Fisheries Research 65: 123-135.

Vega-Velázquez A. 2006. Langosta de la península de Baja California. En: Arreguin-Sánchez F, L Beléndez-Moreno, I
Méndez-Gómez-Humarán, R Solana-Sansores \& C Rangel Dávalos (eds). Sustentabilidad y pesca responsable en México: evaluación y manejo 2001-2005, pp. 155-210. Instituto Nacional de la Pesca, México.

Vega-Velázquez A, G Espinoza-Castro \& C Gómez-Rojo. 1996. Pesquería de la langosta Panulirus spp. En: CasasValdez M \& G Ponce-Díaz (eds). Estudio del potencial pesquero y acuícola de Baja California Sur, México, pp. 227-261. Centro de Investigaciones Biológicas del Noroeste, La Paz.

Vega-Velázquez A, G Espinoza-Castro, RC Gómez \& RP Sierra. 2000. Pesquería de langosta de Baja California. En: Arenas-Fuentes P \& A Díaz de León (eds). Sustentabilidad y pesca responsable en México: Evaluación y manejo 19971998, pp. 265-297. Instituto Nacional de la Pesca, SEMARNAP, México.

Received 8 April 2014 and accepted 23 March 2015

Editor: Claudia Bustos D. 